Available online http://jurnal.unimed.ac.id/2017/index.php/JLT-

Unimed

\title{
LANGUAGE ATTITUDE OF MANDAILINGNESE TEENAGERS IN DESA SIDOJADI KECAMATAN BUKIT MALINTANG KABUPATEN MANDAILING NATAL
}

\author{
Leli Fitri Hasibuan \\ Busmin Gurning \\ Rahmad Husein
}

Diterima Mei 2018; Disetujui Juni 2018; Dipublikasikan Agustus 2018

\begin{abstract}
This study deals with language attitude of Mandailingnese teenagers in Desa Sidojadi Kecamatan Bukit Malintang Kabupaten Mandailing Natal. It was aimed to investigate the language attitude of Mandailingnese teenagers in Desa Sidojadi Kecamatan Bukit Malintang Kabupaten Mandailing Natal, realization of language attitude and the reasons why they have the language attitude such the way it is. This study used qualitative method then the design was descriptive qualitative research. The data of this study were the utterances of Mandailingnese teenagers in Desa Sidojadi Kecamatan Bukit Malintang Kabupaten Mandailing Natal. The source of data of this study was eleven Mandailingnese teenagers who lived in Desa Sidojadi Kecamatan Bukit Malintang Kabupaten Mandailing Natal. Observation and Interview were used to obtain the data. The data were analyzed by using Miles, Huberman, and Saldana's Interactive Model (2014). Based on the data analysis, the Mandailingnese teenagers in Desa Sidojadi Kecamatan Bukit Malintang Kabupaten Mandailing Natal tend to be positive, they realized their language attitude in three domain, they are family domain, friendship domain, and religion domain. They have positive language attitude because they are loyal to use Mandailing language, they feel proud to have Mandailing language, and they have awareness of language norm.
\end{abstract}

Keywords: Language attitude, descriptive qualitative research, Miles, Huberman and Saldana's Interactive Model

How to Cite: Leli Fitri Hasibuan (2018).Language Attitude of Maindailingnese Teenagers in Desa Sidojadi Kecamatan Bukit Malintang Kabupaten Maindailing Natal.JurnalLinguistikTerapanPascasarjanaUnimed, 15 (2): 125-134

*Corresponding author:

ISSN 2407-7410 


\section{INTRODUCTION}

Indonesian country consists of many societies and ethnics, namely, such as: Javanese, Bataknese, Malaynese, Acehnese, Minangnese, Sundanese, Balinese, etc. Because of this, Indonesia has many native languages. Indonesia has 746 native languages (Pusat Bahasa, 2008). Every ethnic have their original place and use their own native language. But sometimes there are people between them that moved to other ethnic's place, that is why there are more than one ethnic in one place. The example is what happen in Desa (village) Sidojadi Kecamatan (district) Bukit Malintang Kabupaten (regency) Mandailing Natal. Beside Mandailingnese people as the original villagers, there are those Javanese people who moved to Sidojadi, as being told before.

Eventhough those Mandailingnese people as the original villagers live in Desa Sidojadi which is in Kecamatan Bukit Malintang Kabupaten Mandailing Natal, they tend to use Javanese language or they mixed their Mandailing language and Javanese language to communicate with their friends, relatives or people around them whether those people whom they talk to Javanese or Mandalingnese.

This is the conversation of Mandailingnese teenagers in Desa Sidojadi Kecamatan Bukit Malintang Kabupaten Mandailing Natal taken as the preliminary data.

Conversation I (the conversation occured at 4th December 2016)

\section{A: Mendung ae.}

Udan nai mabo. Pakean, pakean

(It's cloudy, it almost rain. Clothes)

B: Pakean ku sada, mak.

(My clothes is one)

A: Ojo didele nangkono

(Do not put the clothes there)

B: Men ae

(Let it be)

A: Mengko ireng

(Later it will be black)

Conversation II (the conversation occured at 5th December 2016)

A: Rukiyah, kenal kue seng sekolah MAN seng jenenge Nadia?

(Rukiyah, did you know Nadia that school in MAN?)

B: Nadia? Tanda

(Nadia? Yes, I know her)

B: Eneng koncone Nadia seng kirim salam karo dek nene

(Nadia's friend sends a peace for her) 


\section{A: Akeeran alesanmu}

Jadi pie, si Neni opo si Nadia?

(Too much your reason)

(So how, Neni or Nadia?)

\section{B: Nadia}

(Nadia)

A: Parbuncut iku.

Ora enak iku di gowo, si Neni majo.

Eh, Nal, wes intok sertifikat?Piro nilaimu?

(she likes sulked)

(It's not good to bring her. Better you choose Neni)

(Eh, Nal,did you get your certificate? How about your score?)

B: 70 (pitu pulu)

(Seventy)

\section{A: Inda yakin}

Gowo renelah sertifikate tak delok

(I don't believe)

(Bring here, so i will check it)

The conversations above have been observed by the researcher in Desa Sidojadi itself and that really happens; sometimes they tend to use Javanese language or sometime mixed their language (Mandailing and Javanese language). It is a problem here, the researcher thinks that this phenomenon is relate to the theory of Garvin and Mathiot (1968). And also instead of using Javanese language, the Mandailingnese teenagers should learn deeper to use Mandailing language to keep the existence of Mandailing language.

Teenagers are generations that must preserve their culture, language and ethnic. As I know that the teenagers tend to talk to teenagers each other. By see the previous conversation, the researcher wants to see the Mandailingnese teenagers language attitude in Desa Sidojadi to Mandailing language. In talking the attitude becomes the important thing. The speaker keeps out their existence.

Attitudes are the feelings people have about their own language or the language of others (Crystal 1997:215). Attitude to language is a construct that explains linguistics behavior in particular. Attitudes are mental phenomenon which cannot be examined and cannot observed directly, but they are manifested in people's action (Baker, 1992). People's attitude toward language can be seen from how they think about language, how they use language, with whom they use, where and how often they use the language. Language attitude studies will determine that people's attitude towards language might be positive or negative (Chalak \& Kassaian, 2010). 
Related to the positive or negative attitudes, Garvin and Mathiot (1968) states that language attitude contains three characteristics, they are: (1) language loyalty which motivates a society of language speakers maintain their language, and if it is needed they will protect their language from other languages' inflences, (2) language pride, which motivates the people to make their language as their identity and the unity of the society (3) awareness of the norms, which motivates the people to use their language in carefully and politely and this is the biggest factor which contributes to the activity of using the language (cited in Masruddin,2014). People with these three characteristics towards language are categorized as people who have positive attitudes, but if they do not have or less of these characteristics are categorized as people who have negative attitudes.

In studies about language atitude by Mamun (2012), Chew (2013), Dweik (2015), Siregar (2010), Tsinghua (2011), and Nujraeni (2015), they have same result that all the respondents in their research showed that they have positive attitude.

The researchers Tsinghua (2011) and Dweik (2013), tell about the attitude of students towards English language, and the respondents held the most positive attitudes to learn English, or they like English language and they like those who speak English, or the respondents show the positive attitudes because they normally had more access and exposure to the language and had more oppurtunities to use it.

Abidin (2012) in a study of EFL Students' Attitudes towards learning English Language show that the respondents have a negative attitude towards learning English. The mean score of the three aspects of attitudes towards English among the respondents to be different. Al-Zahrani (2008) proposed that the reason of such negative attitude might have been a reaction to the instructional and traditional techniques used by some of the English language teachers.

Based on the synthesize above, and the phenomenon that happens in Desa Sidojadi Kecamatan Bukit Malintang Kabupaten Mandailing Natal, as the researcher described previously that most of the Mandailingnese teenagers use Javanese language rather than Mandailing language. They still use Javanese language or mixed their language between them eventhough some of them understand Mandailing language as they interact with Mandailingnese people in school, market, or in other places. Because of this, the researcher thinks that there must be something that influences the attitude of Mandailingnese Teenagers in Desa Sidojadi Kecamatan Bukit Malintang Kabupaten Mandailing Natal. 


\section{RESEARCH METHOD}

This research applied descriptive qualitative research design. According to Guba \& Wolf in Bogdan \& Biklen (1992:62) qualitative research is frequently called naturalistic because the researcher frequents places the event she or he is interest in natural occur.

Qualitative research is divided into two studies: case study and multicase study. This research was conducted as a case study. Merriam in Bogdan \& Biklen (1992) state case study is detailed examination of one setting or a single subject, a single depository of document or one particular event. This design was chosen because this research was conducted for one case of language in one region.

\section{FINDINGS AND DISCUSSIONS}

Based on the data analysis, the findings of this study were formulated as following:

1. Types of language attitude in Mandailingnese teenagers in desa Sidojadi Kecamatan Bukit Malintang Kabupaten Mandailing Natal were positive and negative language attitude. However, Mandailingnese teenagers tended to be positive eventhough they lived in the area where Mandailingnese is minority.

2. For the realization of language attitude of Mandailingnese teenagers in Desa Sidojadi Kecamatan Bukit Malintang Kabupaten Mandailing Natal, there were three domain found in the realization of the language attitude, namely: family, friendship, and religion domain. Yet, there were some realizations that cannot be found in Mandailingnese teenagers in desa Sidojadi Kecamatan Bukit Malintang Kabupaten Mandailing Natal namely: education and employee domain.

3. For the reason of realization of language attitude of Mandailingnese teenagers in Desa Sidojadi Kecamatan Buki Malintang Kabupaten Mandailing Natal, it was found that there were six participants who were loyal to the language. It can be concluded that they thought of maintaining the language and valuing the language, they also felt proud of the language and had awareness of the language norm by showing the way they appreciate the language.

After analyzing the data, there were some important points that have to be discussed in this study. Baker (1992) stated that attitude is considered as mentality phenomenon which cannot be examined and observed directly but it is manifested in the form of action. It refers to a hypothetical construct that is used to explain the direction and persistence of human behavior. It can represent internal thought, feelings and tendencies in behavior across variety of a context.

Chalak and Kassaian (2010) stated about language attitude; they argue that someone's language attitude towards a particular language might be either positive or negative.

According to Fishman (1972), there are five domains of language use, namely family domain, friendship domain, religion domain, education domain, and empolyee domain. However, the 
participants in this study that were Mandailingnese teenagers only had three domains of language use which were family domain, friendship domain, and religion domain. There were two domains that were not realized by the participants namely education domain and employee domain. It happened because based on the data given by the local government, there were only 11 Mandailingnese teenagers with the age range 16-18 years old. Most of them went to the school outside of desa Sidojadi, and some of them did not go to school. Moreover, they did not work and that is why it can be concluded that they did not have education domain and employee domain.

According to Garvin and Mathiot (1968:65), the characteristics of language attitude can be seen when someone is loyal to the language, s/he usually uses the language and maintains the language; when someone feels proud to the language, s/he is usually proud to use the language and makes the language as the symbols or as the identity, and when someone has awareness of language norm. In line to the previous description, it was found that the Mandailingnese teenagers in Desa Sidojadi Kecamatan Bukit Malintang Kabupaten Mandailing Natal had positive language attitude to Mandailing language based on the characteristics of language attitude that proposed by Garvin and Mathiot (1968:65). In this study, based on the result interview that have been analyzed, the Mandailingnese teenagers in desa Sidojadi Kecamatan Bukit Malintang Kabupaten Mandailing Natal were loyal to use the Mandailing language - they used Mandailing language in their daily communication and also gave the reason stating that because Mandailing language was their mother tongue and already used the language since they were children.

From the eleven participants of Mandailingnese teenagers, there were six participants that felt proud of using and did not feel shy to use Mandailing language. Moreover, they said that teenagers like them should use Mandailing language so that it became their identity.

Furthermore, there were six of them who were aware to the language norms. In this study, these Mandailingnese teenagers used Mandailing language politely and carefully. They also knew how to appreciate the language - they did some actions to appreciate the Mandailing language.

Moreover, referring to the relevant of the studies Youfoff (2013), Youssef (2012), Rodliyah (2014), Tsinghua (2014), Chew (2013), it can be seen that all participants in their study had positive language attitude. In line to the relevant of the studies, it was found that Mandailingnese teenagers in Desa Sidojadi Kecamatan Bukit Malintang Kabupaten Mandailing Natal had positive language attitude. 


\section{CONCLUSIONS}

Based on the research findings that presented in the previous chapter, there were some important points that can be concluded, they were:

1. Types of language attitude that have been found in the Mandailingnese teenagers in Desa Sidojadi Kecamatan Bukit Malintang Kabupaten Mandailing Natal are positive and negative language attitude. Which is the Mandailingnese teenagers tend to be positive eventhough they lived in the area with Mandailingnese is minority.

2. For the realization of the language attitude, the Mandailingnese teenagers in Desa Sidojadi Kecamatan Bukit Malintang Kabupaten Mandailing Natal realize the language attitude in three domain, they are family domain, friendship domain, and religion domain.

3. For the reason in realization of language attitude of Mandailingnese teenagers in desa Sidojadi Kecamatan Buki Malintang Kabupaten Mandailing Natal, in this study the researcher found that there are six participants that are loyal to the language, it occurs that they thought they have to maintain the language, value the language, and they also feel proud about the language, and have awareness the language norm by showed the way they appreciate the language.

\section{REFERENCES}

Abidin. 2012. "EFL Students' Attitudes toward Learning English Language: The Case of Libyan Secondary School Students".Asian Social Science Journal.Volume 8, No. 2, http://dx.doi.org/10.5539/ass.v8n2p119.html, 08 September 2016

Baker. 2001. Foundation of Bilingual Education and Bilingualism. Clevedon: Multilingual Matters Ltd.

Baron, R.A, \& Byrne, D.E. 2004. Social Psychology $\left(10^{\text {th }}\right.$ ed). USA: Pearson

Bogdan, R.C., \& Biklen, S.K. 1992. Qualitative Research for Education: An Introduction to Theory and Methods. Needham Heights: Allyn and Bacon

Chalak, A.,\&Kassaian, Z. 2010. Motivations and Attitudes of Iranian Undergradute EFL Students towards Learning English. GEMA Online Journal of Language Studies.

Cummins, J. 1984. Bilingual Education and Special Education: Issues in Assesssment and Pedagogy. San Diego: College Hill. 
Dweik,B.S. 2015. "Language Choice and Language Attitudes in a Multilingual Arab Canadian Community: Quebec-Canada: A sociolinguistic Study". Journal of English Linguistics. Volume 3, No. 1, http://www.eajournals.org/wpcontent/uploads/language-choice-and-language-attitudes-in-a-multilingual-arabcanadian-community.pdf, 08 September 2016

Eagley, A.H. \& Chaiken, S. 1993. The Psychology of Attitudes. Harcourt Brace Javanovich College.

Fakhrurrazi. 2013. Attitudes of Indigenous Acehnese People towards Their Vernacular Mintenance in Langsa (Unpublished Magister Thesis). State of University of Medan, Medan.

Fashold, W.R. 1984. The Sociolinguistics of Society: Introduction to Sociolinguistics. Padstow, cornwall, Great Britain.

Fishbein, M. 1967. Attitude and the Prediction of Behavior. In Fishbein, M. (Ed) Readings in Attitude Theory and Measurement. New York: Wiley

Fishman, J.A. 1972. Language in Siciocultural Change. Standford: Standford University Press.

Garvin, P.L \& Mathiot, M. 1968. The Urbanization of the Guarani Language: Problem in Language and Culture in Fishman, J.A. (Ed) Reading in Test Sociology of Language, Mounton:Paris-The Hague

Hafifah. 2016. Javanese Speaker's Attitude toward Their Speech Level in Desa Danau Sijabut (Unpublished Magister Thesis). State University of Medan, Medan.

Handerson, Ane T., Ed, Berla, Nancy, Ed. 1994. A New Generation of Evidence:

The Family is Critical to Student Achievement. Wasington, DC. Retrieved from http://files.eric.ed.gov/fulltext/ED375968.pdf

Holmes, J. 2001. An Intoduction to Sociolinguistics (second edition). Edinburgh Gate: pearson Education Unlimited

Kaplan. P. R. 2004. Adolescence. Boston: Houghton Muffin Company.

Krathwohl, D.R. 1993. Methods of Educational and Social Science Research. Harlow: Longman Publishing Group 
Lincoln, Y.S., \& Guba, E.G. 1985. Naturalistic Inquiry. Beverly Hills: Sage Publication

Mamun, A.Sk. 2012. " Students' Attitudes towards English: The Case of Life Science School of Khulna University". Volume 3, No 1. pp. 200-209. http://irssh.com/yahoo_site_admin/assets/docs/20_irssh-264 v3n1.131231435.pdf. 08 $\underline{\text { September } 2016}$

Miles, M.B., Huberman, A.M., \& Saldana, J. 2014. Qualitative Data Analysis: A Methods Sourcebook Third Edition .USA:SAGE

Nujraeni. 2015. "The Attitudes and Behavior of Using Indonesian Language among the Bureaucrats in South Sulawei Province”. Journal of Language Teaching and eResearch. Volume 6, No. http://www.academypublication.com/ojs/index.php/jltr/article/viewFile, 08 September 2016

Oyedokun, A.W. 2014. "Language Attitudes among the Political Class in Nigeria: Implications for National Development”.International Journal of English Linguistics, $\quad$ Volume $\quad 4, \quad$ No 5. http://www.ccsenet.org/journal/index.php/ijel/article/view/40942, 08 September 2016

Rodliyah, R.S. 2014. "Indonesian Tertiary Students' Attitudes toward the Use of Local Culture VS Target Culture Reading Materials in English Reading ClassVolume 14, No.

1.http://download.portalgaruda.org/article.php?article $=292342 \& \mathrm{val}=5783 \&$ title=indo nesian\%20tertiary\%20students\%c3\%a2\%e2\%82\%ac\%e2\%84\%a2\%20attitudes\%20to wards $\% 20$ the $\% 20$ use $\% 20 \mathrm{of} \% 2010 \mathrm{cal} \% 20$ culture $\% 20 \mathrm{vs} \% 20$ target $\% 20$ culture $\% 20 \mathrm{rea}$ ding\%20materials\%20\%20in\%20english\%20reading\%20class. 08 September 2016

Sinambela, A.D. 2015. Language Attitude of the Toba Bataknese Parents towards Toba Batak Language in Stabat. (Unpublished Magister Thesis). State University of Medan. Medan.

Siregar,F..L, 2010. "The Language Attitudes of Students of English Literature and D3 English at Maranatha Christian University toward American English, British English and Englishes in Southeast Asia, and Their various context of use in Indonesia".Philliphine ESL Journal, Volume 4, http://www.philippine-esljournal.com/wp content/uploads/2014/01/V4_A4.pdf, 08 September 2010

Tsinghua, M.L. 2011. "Current Language Attitudes of Mainland Chinese University Students".Journal of Language Teaching and Research. Volume 2, No. 5, https://www.questia.com/read/1G1-278276707/current-language-attitudes-ofmainland-chinese-university, 08 September 2016 
Triandis, C.H. 1971. Attitude and Attitude Change (Foundations of Social Psychology). New York; Wiley

Van der Tuuk, H.N. 1971.A Grammar of Toba Batak (Tobasche Spraakunst). Netherlands Ministry of Education and Sciences

Murad, K.M. 2007."Language Attitude of Iraqi Native Speakers of Arabic: A Sociolinguistic Investigation.Thesis. University of Kansas

http://bukitmalintang.blogspot.co.id/p/sidojadi.html 